\title{
Land use scenarios and projections simulation using an integrated GIS cellular automata algorithms
}

\author{
Salem S. Gharbia ${ }^{1}$ - Sara Abd Alfatah ${ }^{3}$ - Laurence Gill ${ }^{1}$ - Paul Johnston ${ }^{1}$. \\ Francesco Pilla ${ }^{2}$
}

Received: 29 July 2016/Accepted: 29 July 2016/Published online: 8 August 2016

(c) Springer International Publishing Switzerland 2016

\begin{abstract}
Over the years, urban growth models have proven to be effective in describing and estimating urban development and have consequently proven to be valuable for informed urban planning decision. Therefore, this paper investigates the implementation of an urban growth Cellular automata (CA) model using a GIS platform as a support tool for city planners, economists, urban ecologists and resource managers to help them establish decision making strategies and planning towards urban sustainable development. The area used as a test case is the River Shannon Basin in Ireland. This paper investigates the spatio-temporally varying effects of urbanization using a combined method of CA and GIS rasterization. The results generated from Cellular automata model indicated that the historical urban growth patterns in the River Shannon Basin area, in considerable part, be affected by distance to district centres, distance to roads, slope, neighbourhood effect, population density, and environmental factors with relatively high levels of explanation
\end{abstract}

Salem S. Gharbia

GharbiaS@TCD.ie

Sara Abd Alfatah

sarah.abdalfatah@gmail.com

Laurence Gill

laurence.gill@tcd.ie

Paul Johnston

PJHNSTON@tcd.ie

Francesco Pilla

francesco.pilla@ucd.ie

1 Department of Civil, Structural and Environmental Engineering, Trinity College, Dublin, Ireland

2 Department of Planning and Environmental Policy, University College Dublin, Dublin, Ireland

3 Wesbuilt Construction Managers LLC, New York, USA of the spatial variability. The optimal factors and the relative importance of the driving factors varied over time, thus, providing a valuable insight into the urban growth process. The developed model for Shannon catchment has been calibrated, validated, and used for predicting the future land use scenarios for the future time intervals 2020, 2050 and 2080. By involving natural and socioeconomic variables, the developed Cellular automata (CA) model had proved to be able to reproduce the historical urban growth process and assess the consequence of future urban growth. This paper presented as a novel application to the integrated CA-GIS model using a complicated land use dynamic system for Shannon catchment. The major conclusion from this paper was that land use simulation and projection without GIS rasterization formats cannot perform a multi-class, multi factors analysis which makes high accuracy simulation is impossible.

Keywords Land use · GIS · Cellular automata · Algorithms · Projections

\section{Introduction}

Urbanization, land cover and land use transformation have been universal and important socioeconomic phenomena around the world. Urban growth has been accelerating with the significant increase in urban population (Cohen 2004; DeFries et al. 2010; Preston 1979). Although urbanization promotes socioeconomic development and improves quality of life, it is the most powerful and visible anthropogenic force that has caused the fundamental conversion from natural to artificial land cover in the cities around the world (Clarke et al. 1997; Cohen 2004; DeFries et al. 2010; Preston 1979). 
Rapid urban expansion has marked effects on environment and socio-economy, it usually happens at the expense of prime agricultural land, with the destruction of natural landscape and public open space such as: displacement of agriculture and forest (Kueppers et al. 2004; Sim and Balamurugan 1991; Simmie and Martin 2010; Chen et al. 2010); decline in wetlands and wildlife habitats (Serneels and Lambin 2001); local impact on hydrology, degradation of ecosystem compositions and global impact of changes in atmospheric compositions (Foley et al. 2005). The spatiotemporal process of urban development and the socialenvironmental consequences of such development deserve meticulous study by urban geographers, planners, and policy makers because of the direct and profound impacts on human beings (Sim and Balamurugan 1991; Simmie and Martin 2010; Chen et al. 2010; Cohen 2004; DeFries et al. 2010; Preston 1979; Evans 2006).

In order to obtain better understanding of urban growth process, recent issues related to urban growth have attracted increasing attention in literature, ranging from spatial and temporal land cover patterns, the factors affecting the urban growth, to urban growth scenarios by using Land Cover maps, Geographic Information Systems (GIS) and different modelling techniques (Li 2014; Pijanowski et al. 2002; Lambin 1997; Liu et al. 2005; Herold et al. 2003, 2005).

Land use/cover models have been proven to be effective in describing and estimating urban development and have consequently proven to be valuable for informed urban planning decisions (Munshi et al. 2014; Herold et al. 2003; Sim and Balamurugan 1991; Cohen 2004). Cellular automata (CA) have gained popularity as modelling tools for urban process simulation. Since the pioneering work of Tobler (1979), several approaches have been proposed for modifying standard Cellular automata (CA) in order to make them suitable for urban simulations (White et al. 1997, 1999; Itami 1994; White and Engelen 1993). Cellular automata based models are a powerful tool for representing and simulating spatial processes underlying the spatial decisions due to their accuracy, simplicity, flexibility and intuitiveness. This paper investigates the implementation of an urban growth Cellular automata (CA) model in the River Shannon Basin area (Gharbia et al. 2015, 2016a, b) in order to produce future land cover scenarios to be used in the dynamic water balance simulation for the Shannon catchment, which can be extremely helpful for hydrologist and water planners. The focus is on the investigation of spatio-temporal dynamics of land cover change pattern from land cover maps and simulation of the urban growth. The main objectives are to: (1) extract and compare the historical land cover information for the investigation area through the interpretation of land cover maps and the using of quantitative measures; (2) identify any strategies currently formulated by government to manage the extent and nature of urban growth in Ireland; (3) implement and evaluate the performance of the proposed integrated model between CA and GIS to predict future urban expansion; (4) quantify the future urban expansion in the River Shannon Basin area and investigating the spatiotemporal dynamics effects of the factors on urban growth to provide insight into how driving factors contribute to the urban growth.

\section{Materials and methods}

The River Shannon, the focus of this study, is the largest transboundary river system and catchment in the island of Ireland and one of the most important water and power resources in the Republic of Ireland.

\section{Cellular automata (CA)}

Cellular automaton can be defined as a self-operating machine that "processes information, proceeding logically, inexorably performing its next action after applying data received from outside itself in light of instructions programmed within itself" (Liu and He 2009). However Cellular automata (CA) are models that simulate complex systems, they have been defined as very simple dynamic spatial systems (Torrens 2000; Reinau 2006; Liu and He 2009). In CA the state of each cell in an array depends on the previous state of the cells within a neighbourhood, according to a set of transition rules (White et al. 1999; White and Engelen 1993; White et al. 1997). Despite their simplicity some classes of CA are capable of "universal computation"(Wolfram 1984), which means that some types of CA can have reproducing behaviours with high level of complexity, such as of physical, biological or social complex systems. CA has a remarkable potential for modelling complex spatio-temporal processes (Deutsch and Dormann 2007; Barredo et al. 2003), and some simple $\mathrm{CA}$ have the ability to produce complex forms through simple set of rules (Deutsch and Dormann 2007; Barredo et al. 2003).

Many processes in nature and in social systems are somehow complicated process to be modeled through linear equations, therefore non-linear differential equations are needed in such cases. In these kinds of equations, a magnitude $(X)$ in a time $(t+1)$ is the consequence of the magnitude in the preceding time $(\mathrm{t})$. This configuration defines a basic non-linear differential equation (Barredo et al. 2003):

$\boldsymbol{X}_{(t+1)}=\boldsymbol{f}\left(\boldsymbol{X}_{\boldsymbol{t}}\right)$. 
These equations, although fully deterministic, can produce a very dynamic behaviour, from stable points and limit cycles to chaotic regimes (strange attractors) (Wolfram 1984; May 1976). Moreover, the behaviour of non-linear differential equations may be indistinguishable from the one produced by a random process.

Wolfram (1984) stated that Cellular automata have been considered as spatial idealizations of partially differential equations with discrete space and time, thus it is not strange that CA show behaviours analogous to non-linear ordinary differential equations. Therefore, it is not surprising that $\mathrm{CA}$ is capable of producing and simulating complex spatial processes showing non-linear dynamics such as some socio-spatial processes (i.e. spatial segregation of socio-economic groups), and moreover CA produce spatial patterns that show chaotic behaviour in the sense of irregular dynamics in a deterministic system. In these kinds of systems the behaviour depends on its own internal logic (Barredo et al. 2003).

In CA, cells are the basic and smallest spatial unit in a cellular space which must manifest some adjacency or proximity ( $\mathrm{Li}$ and Yeh 2000). They are typically represented by a regular two-dimensions grid usually composed of square cells, although some researchers have proposed hexagonal cells to obtain a more homogeneous neighbourhood (Iovine et al. 2005). Moreover, the regular cell can be modified by using irregular tessellations such as Voronoi polygons (Shi and Pang 2000). The cells are characterised by the following:

- Size the cell size is the area of the landscape each cell will cover. The use of cell resolution is either based on the availability of data or on the convenience for computation. Different researcher used different cell size in their studies, which can be related to the different conditions of the study area (White and Engelen 1993; Cho and Swartzlander 2007; Chen and Mynett 2003). In this study, a $100 \mathrm{~m} \times 100 \mathrm{~m}$ cell size has been used.

- State the cell state defines the attributes of the system. Each cell can take only one state from a set of states at any one time. In urban-based cellular automata models, the states of cells may represent the types of land use or land cover, such as urban or rural, or any specific type of land use; or it may be used to represent other features of the urban area, such as social categories of populations as was proposed by (Portugali and Benenson 1995).

- Neighbourhood a cell's neighbourhood is the region that serves as an input to assess the neighbourhood effect in the transition rules. This effect is calculated as a function of a cell's own state and the state of the cells within its neighbourhood (M'nard and Marceau 2005;
Balzter et al. 1998; Wolfram 1983). The traditional neighbourhood types for two-dimensional raster based Cellar automata (CA) models are: Von Neumann neighbourhood and rectangular (Moore) neighbourhood (Flache and Hegselmann 2001; Vezhnevets and Konouchine 2005). The Von Neumann neighbourhood consists of four cells which include the North, South, East, and West neighbours of a cell in question. The Moore neighbourhood consists of eight cells which include the cells defined in the von Neumann neighbourhood as well as cells in the North-west, North-east, South-east, and South-west directions, which are commonly used in CA model applications (Wu 1998; Lau and Kam 2005; Flache and Hegselmann 2001; Vezhnevets and Konouchine 2005). Neighbourhood size defines the extent of interactions between land use and the dynamics of the system (Caruso et al. 2005). In general, the effect of neighbourhood cells decreases with the increasing distance to the central cell (Barredo et al. 2003).

The definition of the transition rules of a CA model is the most important part to achieve realistic simulations of land use and land cover change (Verburg et al. 2004b). This is the key component of CA because these rules represent the process of the system being modelled, and are thus essential to the success of a good modelling practice (White 1998). The traditional transition rules are dependent on the current cell state and its neighbourhood effects (Jenerette and Wu 2001; Li et al. 1990; Liu et al. 2008). In the context of urban growth, however, a variety of factors have significant impacts on urban growth, such as physical suitability for a specific land use, accessibility, socioeconomic factors, urban planning factors, and stochastic disturbance related to the complexity of human system. Consequently, the transition rules should consider various factors to allow for more realistic simulation (Jokar Arsanjani et al. 2013; Li et al. 1990; Liu et al. 2008). In addition, traditional CA models employ only one uniform transition rule for different periods and sub-regions, while the urban growth process may vary over time and space, so it is necessary to apply different transition rules to the specific characteristics of each period and area. Spatial and temporal varying transition rules can be obtained by calibration (Geertman et al. 2007; Li et al. 1990; Liu et al. 2008).

Urban development resembles the behaviour of a cellular automaton in many aspects. The space of an urban area can be regarded as a combination of a number of cells, each cell taking a finite set of possible states representing the extent of its urban development. The state of each cell evolves in discrete time steps according to some local rules. 


\section{Data setup}

This section describes the details of preparation the data sets that are used in feeding the fuzzy constrained cellular automata model of urban development through GIS platform, which means cellular automata model of land use simulation uses fuzzy-sets and fuzzy logic approaches. The model assigns membership of land uses to multiple states of model's parameters are applied to represent the nondeterministic status of land use development controls.

The CORINE (Co-Ordinated Information on the Environment) data series was established by the European Community (EC) as a means of compiling geo-spatial environmental information in a standardized and comparable manner across the European continent. The CORINE Land Cover is a vector map with a scale of 1:100,000, a minimum cartographic unit (MCU) of 25 ha and a geometric accuracy better than $100 \mathrm{~m}$. It maps homogeneous landscape patterns, i.e. more than $75 \%$ of the pattern has the characteristics of a given class from the nomenclature (EPA 2012). In Ireland, this nomenclature is a 3-level hierarchical classification system and has 34 classes at the third and most detailed level, as detailed in (EPA 2015). The first iteration of the data series covered the reference year of 1990 with subsequent releases covering the years 2000, 2006 and 2012. The first dataset in 1990 provided a 'snapshot' baseline of the geographical distribution of natural and built environments across Europe. Through this baseline and subsequent updating of changes, CORINE has become a key data source for informing environmental and planning policy on a national and European level.
The land use modelling especially urban growth is a complex process which involves the interaction influence of various factors. According to data availability, the following set of variables representing natural, socioeconomic, spatial policies and neighbourhood factors were selected to design this study (Table 1):

- Physical factor a Digital Elevation Model (DEM) obtained from Eurosat at a spatial resolution of $25 \mathrm{~m}$ of the study areas was used to represent topography. Slope gradient was derived from the elevation surface using 3D analyst package toolbox in ArcMap.

- Socioeconomic factors The influence of the socioeconomic conditions in the region can be best characterized by the accessibility of that location to socioeconomic centres, which has a significant effect on urban growth pattern (Li et al. 2013; Verburg et al. 2004b). Transportation is an important factor in accelerating urban development and attracting new development. A good transportation network increases the accessibility of land (Miller 1999; Couclelis 2000). Consequently, areas with good accessibility are more easily selected for urban development. Major roads (motorways and national primary roads) and minor roads (national secondary roads and regional roads) were considered in this study. Because of the infrastructure construction, the traffic system changes all the time, therefore, in this study it was assumed that the roads dataset remained unchanged during one period (2000-2012). Population are one of the main drivers of urban growth. More urban land will be required to satisfy further growth of urban population in the future.

Table 1 List of the used datasets in this study

\begin{tabular}{|c|c|c|c|}
\hline Variable & Year & Description & Sources \\
\hline \multicolumn{4}{|l|}{ Physical factor } \\
\hline Slope & & $\begin{array}{l}\text { It was derived from Digital Elevation map (DEM), resolution of } \\
25 \mathrm{~m}\end{array}$ & European Statistics, Eurostat \\
\hline \multicolumn{4}{|c|}{ Socioeconomic factor } \\
\hline Dist2Majr & 2010 & Distance to major road & $\begin{array}{l}\text { Irish Environmental Protection Agency } \\
\text { (Irish EPA) }\end{array}$ \\
\hline Dist2Minr & 2005 & Distance to minor road & Irish EPA \\
\hline Dist2Town & 2006 & Distance to towns/cities & Central Statistics Office Ireland (CSO) \\
\hline PopDen & 2002 & Population density collected using electoral divisions units & Central Statistics Office Ireland (CSO) \\
\hline \multicolumn{4}{|c|}{ Spatial Policy factor } \\
\hline Environmental & $\begin{array}{c}\text { Published } \\
2013 \\
\text { Updated } \\
2015\end{array}$ & $\begin{array}{l}\text { Special protection areas, special areas of conservation and natural } \\
\text { heritage areas }\end{array}$ & $\begin{array}{l}\text { The National Parks and Wildlife Service } \\
\text { (NPWS) }\end{array}$ \\
\hline \multicolumn{4}{|c|}{ Neighborhood factor } \\
\hline Dist2Urban & 2000 & Distance to existing urban area & $\begin{array}{l}\text { Extracted from Land Cover Map (Irish } \\
\text { EPA) }\end{array}$ \\
\hline
\end{tabular}


Table 2 Land cover classes used in the simulation

\begin{tabular}{ll}
\hline $\begin{array}{l}\text { Land cover } \\
\text { classes }\end{array}$ & Description \\
\hline $\begin{array}{l}\text { Water bodies } \\
\text { Wetlands }\end{array}$ & $\begin{array}{l}\text { Stream courses, Water bodies, Coastal lagoons, Estuaries, Sea and ocean } \\
\text { Inland marshes, Peat bogs, Salt marshes, Salines, Intertidal flats }\end{array}$ \\
$\begin{array}{l}\text { Urban area } \\
\text { Road and rail networks and associated land, airports, mineral extraction sites, dump, green urban areas, sport and leisure } \\
\text { facilities, continuous urban fabric, discontinuous urban fabric, sea port, industrial and commercial, construction site }\end{array}$ \\
$\begin{array}{c}\text { Nonicultural } \\
\text { areas }\end{array}$ \\
$\begin{array}{c}\text { Forest } \\
\text { areas of natural vegetation }\end{array}$ \\
$\begin{array}{c}\text { Broad leafed forest, coniferous forests, mixed forest, natural grassland, moors and heathlands, transitional woodland-scrub, } \\
\text { beaches, dunes, sand, bare rocks, sparsely vegetated areas }\end{array}$
\end{tabular}

The population variable was represented by the population density of Electoral Divisions (EDs) administrative units.

- Spatial Policy factor Policy variables affect the urban growth by acting as constraints or incentives to development (Buss 2001; Jantz et al. 2004). Development Plans constitute the basic policy document of the land use and development system in Ireland. Land use development policy is primarily articulated through the designation of land use objectives specific to particular lands within the planning authority's jurisdiction. In this study, initial attempts were made to apply direct translation of the development plans into zoning maps for the CA model. The used spatial datasets were sampled to the same cell size of $100 \mathrm{~m} \times 100 \mathrm{~m}$, which was sufficient to capture the detailed information about urban dynamics while keeping the volume of computation manageable.

\section{Model setup and the integration with GIS platform}

Modelling geographical phenomena and processes using CA simulations is based on constructing regular spatial tessellation models. These models are naturally related to raster-based GIS, thus leading to the main advantage arising from the integration of GIS and CA models, which is the use of the GIS geo-processors (Wagner 1997; Takeyama and Couclelis 1997; Batty et al. 1999; Clarke and Gaydos 1998; Li and Yeh 2000). The application of cellular automata in modelling urban development is "virtually impossible without the data management capabilities of GIS" (Clarke and Gaydos 1998). Therefore, applications of CA in geography are mostly integrated with a GIS, and consequently it can work at high spatial resolution with computational efficiency.

In this study, a cellular automata GIS based algorithm has been implemented in the GIS environment using raster data forms in order to simulate the urban expansion and land use trends in the Shannon River catchment, then the calibrated model has been used to produce future land use scenarios. CA model expects all input maps to be strictly comparable; they must cover the same area and have the same resolution, various spatial analysis techniques in ArcGIS were applied to process the raw data and verify the quality and consistency of data collected from different sources. CORINE Land use maps of 2000, 2006 and 2012 were used in this study (EPA 2012, 2015). For input into the CA model, the 34 classes in the land use maps were reduced to five by aggregating related classes from the initial land use layer. This was required because it would be too computationally intensive to model each individual land use class separately. The main five land cover classes were water bodies, wetlands, urban area, agricultural and forest ( $\mathrm{Li} \mathrm{2014)}$ as detailed in Table 2.

The CA model requires the Land Cover maps to be in raster format. Using ArcGIS 10.1 conversion tool, the Land Cover maps were converted from vector to raster grid according to the maximum area principle which assigns the cell type parameter to set to Maximum area, the single feature with the largest area within the cell yields the attribute to assign to the cell. The final modelling area maps were converted into ASCII raster format. Following the maps classification, the spatial patterns and trends over time were examined using the Land Cover data, Continual and historical, information about the land cover change is essential for urban growth analysis, in which land cover information serves as one of the major input criteria for the model.

Change detection analysis was used to analyses patterns of Land Cover change during the study period. Change detection can be defined as the process of identifying differences in the states of an object by observing it at different times (Singh 1989). There are several methods can be used for change detection, like Image differencing, principal component analysis and post classification detection (Lu and Weng 2004). In this study post classification was selected as a change detection method to identify the changes in land covers over 
different time intervals for the River Shannon Basin Area. The method involves independent classification results for each end of the time interval of interest, followed by a pixel by pixel comparison to detect land cover changes (Coppin et al. 2004). The post classification method generated a two-way cross matrix, providing "from-to" land cover conversion information (Tables 3, 4). The change detection analysis was conducted primarily through the use of ArcGIS by using the overlay tool. A new thematic map containing different combination of "from-to" change information was also produced for each period. GIS has been applied widely to visualize the spatio-temporal process of physical changes (Batty 1998; Clarke and Gaydos 1998).The main advantage of this method lies in the fact that each land use map is classified separately; moreover, the Land Cover matrix produced was also used to get the conversion rate from one land use to another between two periods.

The overall trend analysis and visualization of the data in ArcGIS demonstrate that the urban areas of River Shannon Basin area had significantly increased from $1.36 \%$ in 2000 to $1.55 \%$ in 2006 , the overall change percentage from 2000 to 2006 is $14.4 \%$, which is 35.94 $\mathrm{Km}^{2}$ increase in the urban area. The analysis showed that urban area cover increased at the expense of agricultural and forest cover. Whereas forest cover increased at the expense of wetlands and agricultural covers, as the trend toward forest regeneration on abandoned land continued. The analysis showed the forest cover had increased from $11.81 \%$ in 2000 to $12.20 \%$ in 2006 with an overall increase of $3.3 \%$ which is $70.81 \mathrm{~km}^{2}$. Moreover, the agricultural cover had been increased as well from $72.79 \%$ in 2000 to $73.93 \%$ in 2006 at the expense of wetlands, water bodies and forest cover mainly, with an overall increase of $209.12 \mathrm{~km}^{2}$, i.e. $1.56 \%$. The wetlands had been reduced severally with a percentage of $11.5 \%$ in 2000 to $9.93 \%$ in 2006 , that is a reduction of $288.55 \mathrm{~km}^{2}$, with the overall reduction of $-13.7 \%$.

On the other hand, the urban area increased from $1.55 \%$ in 2006 to $1.59 \%$ in 2012 at the expense of agricultural and forest covers mainly, with an overall increase of $2.5 \%$ which is $7.13 \mathrm{~km}^{2}$. The recession from 2007 to $2012 \mathrm{had}$ highlighted the major impacts on the environment and society of a contraction in economic activities and development decisions, this might be one of the reasons that the urban expansion from 2006 to 2012 is less than urban expansion during 2000-2006. The forest area had been slightly increased from $12.20 \%$ in $2006 \%$ to $12.37 \%$ in 2012 at the expense of wetlands and agricultural area, with an overall increase of $1.36 \%$, i.e. $30.55 \mathrm{~km}^{2}$. The agricultural cover had been reduced slightly from $73.92 \%$ in 2006 to $73.79 \%$ in 2012; the overall reduction land was

Table 3 Transition matrix for Shannon catchment based on land cover data for 2000 and 2006, units in kilometre square

\begin{tabular}{|c|c|c|c|c|c|c|c|}
\hline \multirow[t]{2}{*}{ Land cover categories 2006} & \multicolumn{7}{|c|}{ Land Cover categories 2000} \\
\hline & Water bodies & Wetlands & Urban area & Agricultural & Forest & Total 2006 & $\% 2006$ \\
\hline Water bodies & 427.08 & 2.31 & 0.14 & 7.75 & 1.93 & 439.21 & 2.4 \\
\hline Wetlands & 9.43 & 1531.54 & 1.25 & 114.05 & 167.25 & 1823.52 & 9.9 \\
\hline Urban area & 0.6 & 0.92 & 229.84 & 48.3 & 5.95 & 285.61 & 1.6 \\
\hline Agricultural & 24.98 & 270.61 & 17.79 & $12,838.66$ & 429.82 & $13,581.86$ & 73.9 \\
\hline Forest & 4.44 & 306.69 & 0.65 & 363.98 & 1565.3 & 2241.06 & 12.2 \\
\hline Total 2000 & 466.53 & 2112.07 & 249.67 & $13,372.74$ & 2170.3 & $18,371.26$ & 100.0 \\
\hline$\% 2000$ & 2.5 & 11.5 & 1.4 & 72.8 & 11.8 & 100.0 & \\
\hline
\end{tabular}

Table 4 Transition matrix for Shannon catchment based land cover data for 2006 and 2012, units in kilometre square

\begin{tabular}{|c|c|c|c|c|c|c|c|}
\hline \multirow[t]{2}{*}{ Land cover categories 2012} & \multicolumn{7}{|c|}{ Land Cover categories 2006} \\
\hline & Water bodies & Wetlands & Urban area & Agricultural & Forest & Total 2012 & $\% 2012$ \\
\hline Water bodies & 406.62 & 5.24 & 0.83 & 22.5 & 4.47 & 439.66 & 2.39 \\
\hline Wetlands & 5.22 & 1637.13 & 0.86 & 112.73 & 54.36 & 1810.3 & 9.85 \\
\hline Urban area & 0.83 & 1.15 & 243.1 & 45.62 & 2.04 & 292.74 & 1.59 \\
\hline Agricultural & 22.37 & 114.29 & 39.46 & $13,202.12$ & 178.71 & $13,556.95$ & 73.79 \\
\hline Forest & 4.17 & 65.71 & 1.36 & 198.89 & 2001.48 & 2271.61 & 12.37 \\
\hline Total 2006 & 439.21 & 1823.52 & 285.61 & $13,581.86$ & 2241.06 & $18,371.26$ & 100 \\
\hline$\% 2006$ & 2.39 & 9.93 & 1.55 & 73.93 & 12.20 & 100 & \\
\hline
\end{tabular}




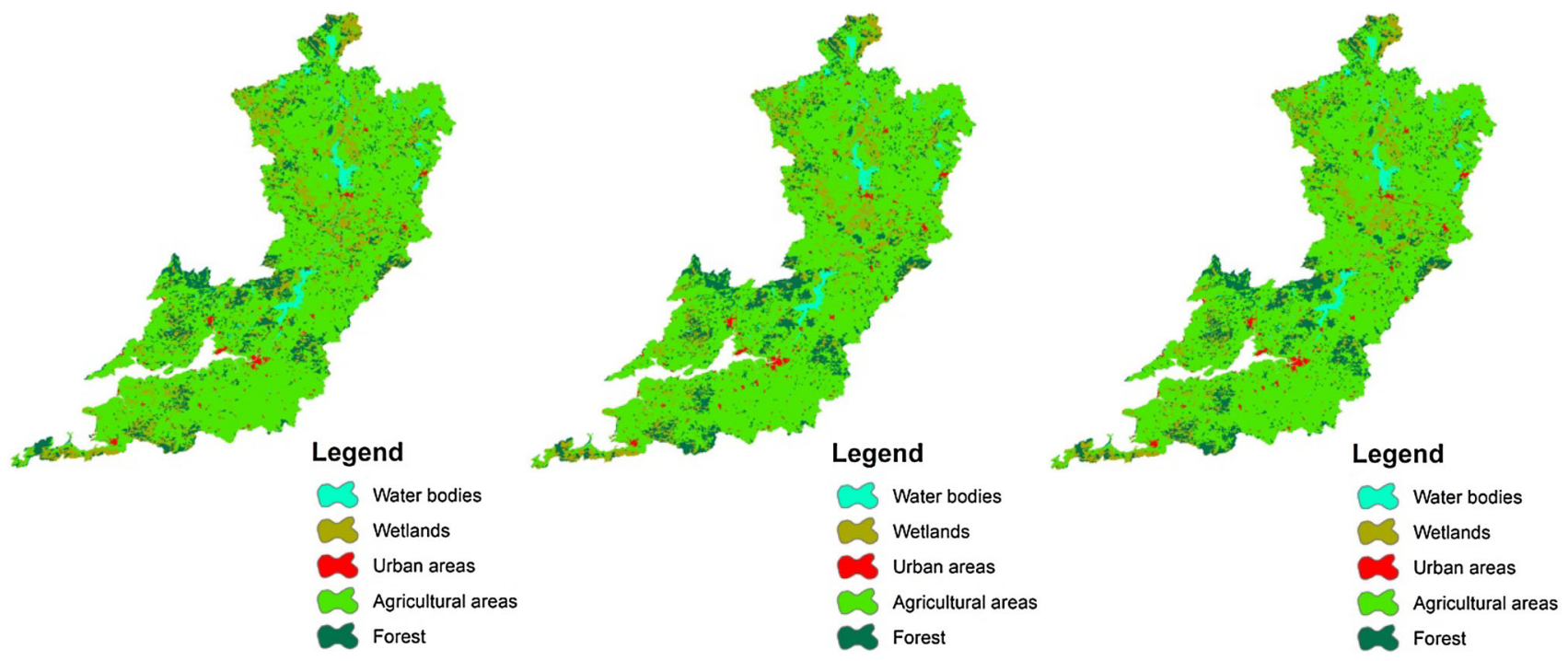

Fig. 1-3 Re-classed land cover maps for 2000, 2006 and 2012

$24.91 \mathrm{~km}^{2}$ which is $-0.18 \%$. Also, the wetlands had witnessed a small reduction from $9.93 \%$ in 2006 to $9.85 \%$ in 2012 with an overall reduction of $13.22 \mathrm{~km}^{2}$, which is equivalent to $-0.72 \%$. Figures $1-3$ show the Land Cover classification for the periods of 2000, 2006 and 2012.

\section{Simulation driving factors}

One of the main input for CA urban expansion simulation is land suitability map. Land suitability map overlay generated by the mechanism overlaying the driving-factor maps as well as several restrictions, such as zoning, protected areas, slope, hazards, etc. In order to prepare the suitability map, driving factors maps, distance to major and minor roads, population density, distance to towns/cities and distance to existing urban area, should be prepared first. Secondly, constrain maps should be prepared which are slope and protected areas in this study.

Transportation Network Transportation plays an important part in urban growth because a good transportation increases the accessibility of land and decreases the cost of construction (Reilly et al. 2009; Du and Mulley 2006; Rietveld and Bruinsma 2012; Geurs and Van Wee 2004). Consequently, areas with good accessibility are more easily selected for urban development. Major roads (motorways and national primary roads) and minor roads (national secondary roads and regional roads) were considered in this study. The data map used for the major roads was for 2010 and for the minor roads was for 2005. Because of the infrastructure construction, the traffic system changes all the time, therefore, in this study it was assumed that the roads dataset remained unchanged; therefore, these transportation maps were entered for Land Cover 2000 assuming the transportation network were similar during that period. The accessibilities were calculated as the Euclidean distance using the Spatial Analyst geo-processor. The Euclidean distance tools gives the distance from each cell in the raster to the closest source based on the straight-line distance. Figures 4 and 5 show the Euclidean distance from major and minor road respectively.

Population density Population is one of the main drivers of urban growth (Liu et al. 2005; Meyer and Turner 1992). The population variable was represented by the population density of Electoral Divisions (EDs) administrative units. The data was obtained by Central Statistics Office Ireland (CSO), which has been the official body in charge of the collection of the last five censuses in the Republic of Ireland in 1986, 1991, 1996, 2002, 2006 and 2011.

For the Shannon River Basin area model population data for 2000 was required to use it as a factor in order to simulate the baseline period land use. The population data for year 200 was not available, so the population for year 2002 was used instead. To prepare the population density map to be input into the CA model, first the population density was calculated for all the Electoral Divisions for the year 2002, and then the data were extracted into three maps: small population, medium population and high population maps, in order to present the population data in the form of fuzzy data. Using this method the weighting parameter for the high population map would be higher than the medium population map, and the medium population map will have higher weighting parameter than the small population map, which basically means that the probability of the urban land expansion is higher around 


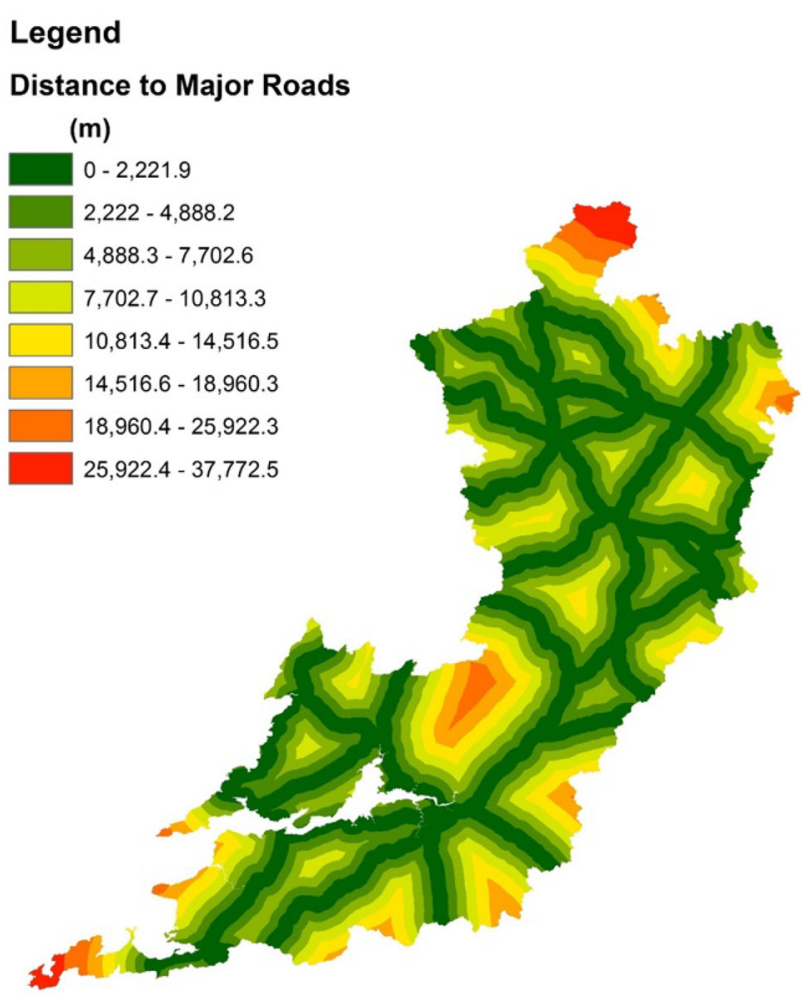

Fig. 4 Driving factor of distance to major roads

the highly populated area than it is in the area with medium population, also the probability of the urban expansion around the area with medium population is higher than the area with small population. Figures 6-8 show the distance to the different pupation categories.

Distance to towns/cities and existing communities The influence of the socioeconomic conditions in the region can be best characterized by the access that a location has to socioeconomic centres, which has a significant effect on urban growth pattern (Verburg et al. 2004b; Li et al. 2013).

It is logical to think that new residential areas usually grow near or adjacent to existent residential areas, i.e. there is high probability that the urban growth would happen closer to the town/cities centres or to the existing urban areas due to the neighbourhood effect. These centres can reflect the accessibility effect on land use development at different levels.

Distance raster maps were prepared to the town/city centres to be input into the CA model. Figures 9 and 10 show the distance raster maps to the existing communities.

\section{Simulation constrain factors}

Topographic Data Suitability represents the degree of relevance of each cell to each land use type, according to a

\section{Legend \\ Distance to Minor Roads}

(m)
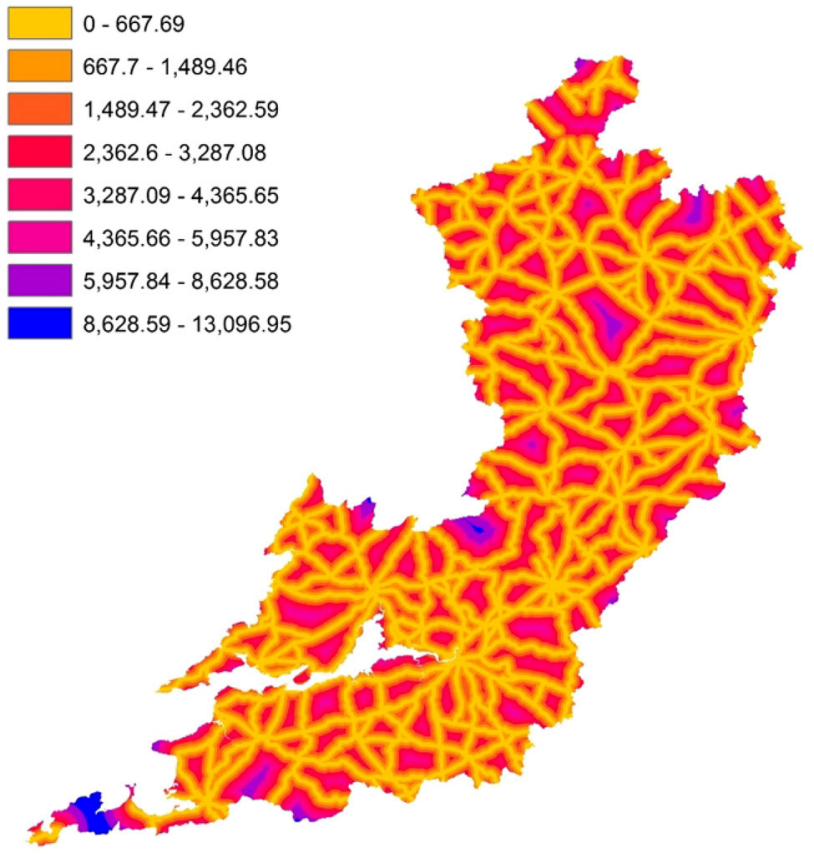

Fig. 5 Driving factor of distance to minor roads

set of predefined criteria (Wu and Webster 1998; Rounsevell et al. 2006; Malczewski 2004). Thus, land use suitability displays locations that fulfil suitability criteria defined for each land use class, therefore the slope was used as one of the constraints to the River Shannon Basin Area development, as the slope has been used as a constrain for the Greater Dublin Region project (Shahumyan et al. 2009).

In the study of (Shahumyan et al. 2009) to stimulate the future urban growth for the Greater Dublin Region, the values of the slope suitability were obtained from researchers at the European Commission Joint Research Centre (EC-JRC). During the researching period the ECJRC was contacted in order to get the slope suitability values for the River Shannon Basin Area, but no response received. Therefore, the same slope suitability values of the Greater Dublin Region were used, because the study is based in an Irish area and the topography might be similar.

The Digital Elevation Map (DEM) was obtained from EUROSAT, the slope value in degree was calculated from the DEM data using Spatial Analyst Tools. The slope values were divided into two categories, suitable and nonsuitable for the urban development. The CA understand these divisions in terms of 0 and 1 , so 0 means the land use is not suitable for development and 1 is suitable. The slope 


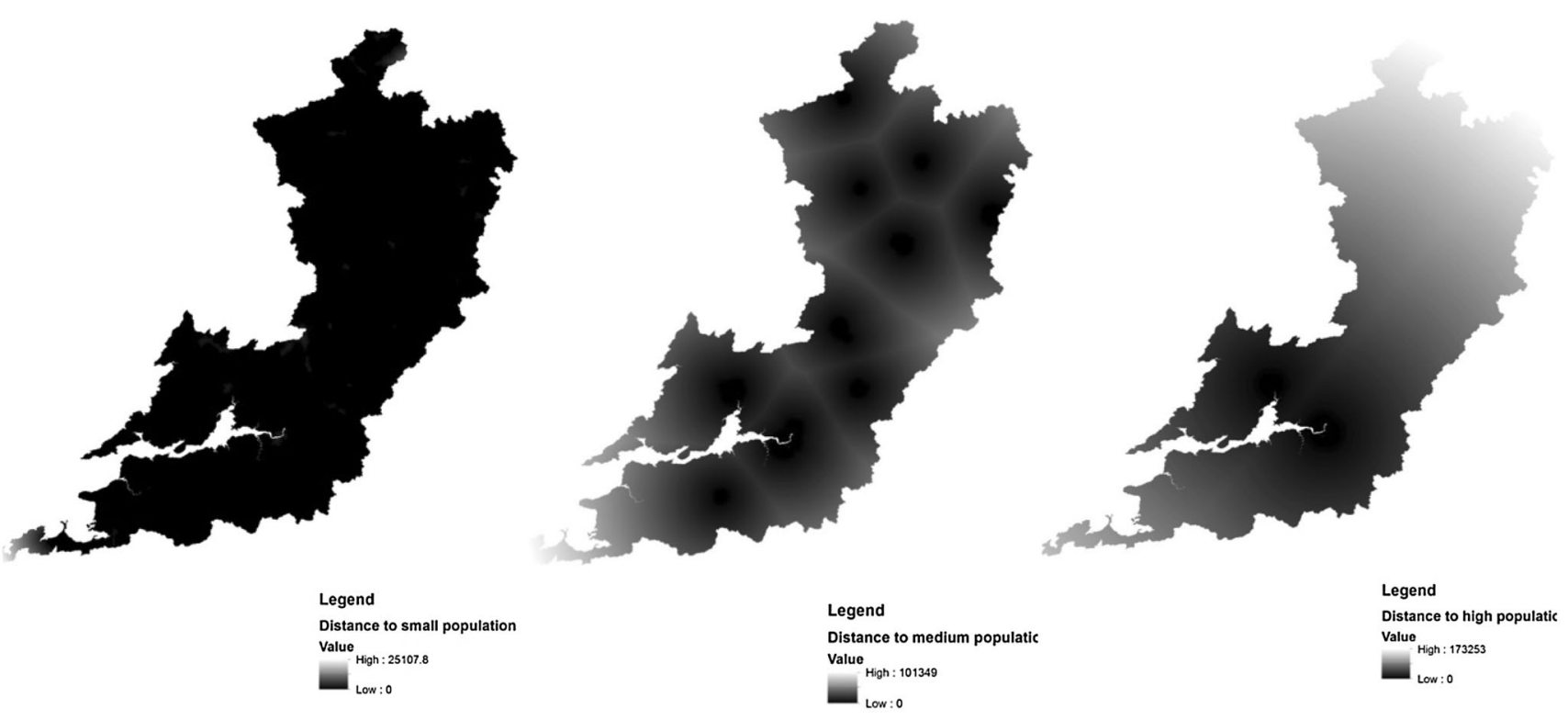

Fig. 6-8 Distance (m) to small, medium and high populated electoral divisions

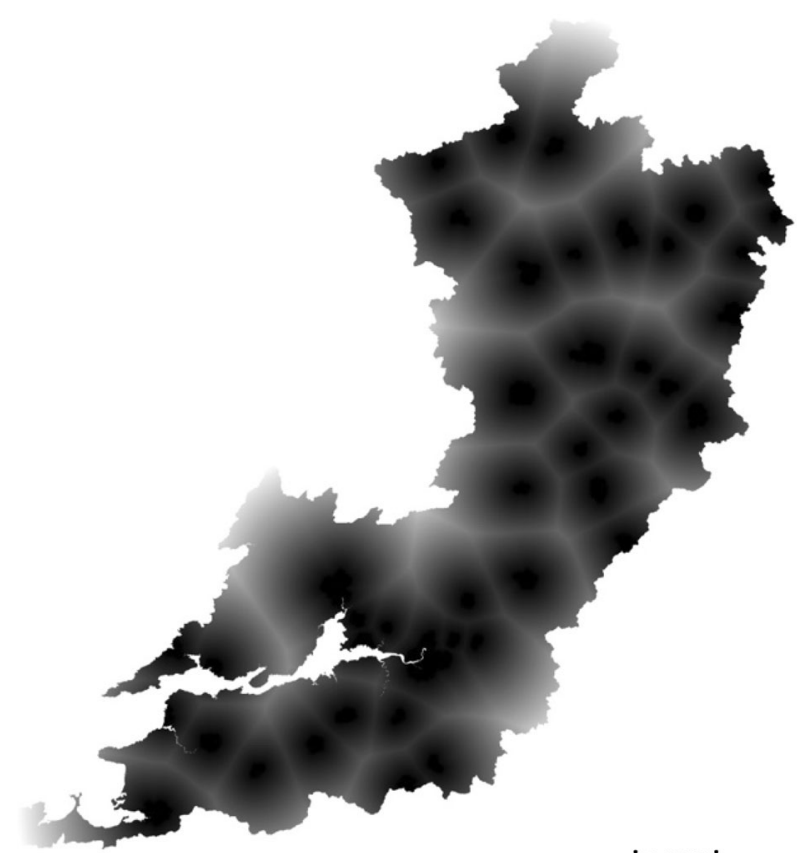

Legend

Distance to towns

Value

High : 51594.1

Low : 0

Fig. 9 Distance to towns/cities raster map

map used in the model was as follow: $1=$ for the slope between $0^{\circ}$ and $25^{\circ}$, and $0=$ for slope above $25^{\circ}$, i.e. the urban development is not possible above $25^{\circ}$.

The slope map was initially converted into raster and then using the reclassify tool in spatial analyst tools in

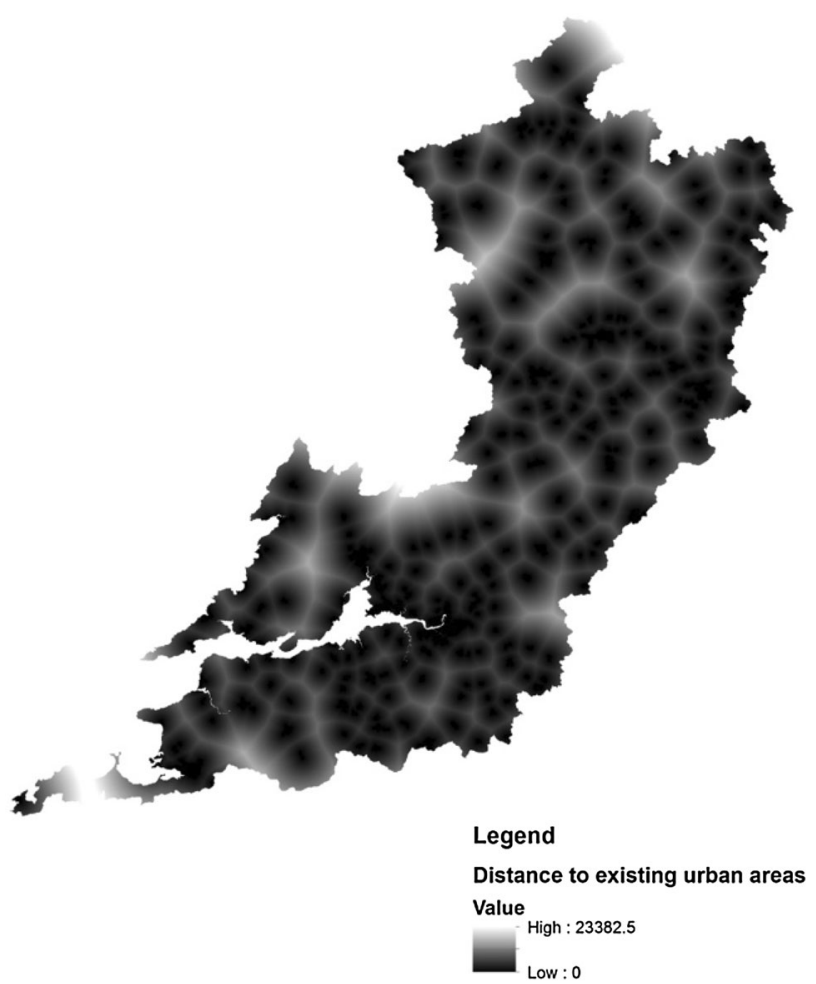

Fig. 10 Distance to existing urban areas raster map

ArcGIS the divisions of 0 and 1 was created. The slope constraint was then merged with the constraint from zoning calculated in the following section to create the constraint map in Fig. 11. 
Zoning maps This study initial attempts were made to apply direct translation of the development plans into zoning maps for the CA model. This process was however time consuming, therefore an alternative approach was implemented to avoid this problem, whereby a zoning map was developed which included Special Areas of Conservation (SACs), protected as Special Protection Areas (SPAs) and Natural Heritage Areas (NHAs). These areas were defined as constraints, where the development was limited. The three maps were converted into raster format and then using the reclassify tool in spatial analyst tools in ArcGIS the divisions of 0 and 1 was created. Where 0 represent all protected areas in which the development is restricted.

The CA model used in this study accept only one constraint map, therefore all the four maps, slope, SACs, SPAs and NHAs, were combined together into one constraint map using the raster calculator tool in spatial analyst tools in ArcGIS 10.1. Figure 11 shows all the constraint map.

\section{Cellular automata setup on GIS platform}

In this study a strong coupling approach was adopted to implement a CA model within a GIS environment. There are several reasons for using this approach, which are the following:

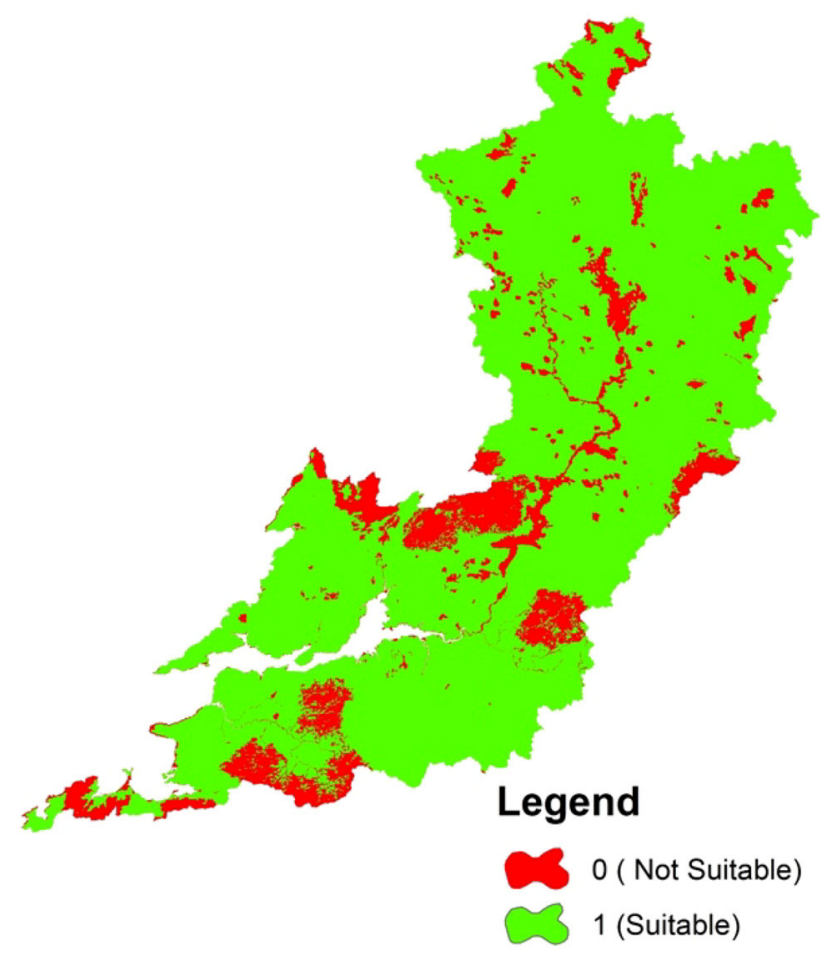

Fig. 11 Constraint map for Shannon Basin
1. The main reason was that data were initially processed and stored in ArcGIS and then later converted into raster grid files, the simulated outputs of the model were also stored as raster grid files in ArcGIS. This feature was especially advantageous during the model calibration process when simulation results were compared and fitted with data illustrating actual Land Cover.

2. The spatial visualization capability was a very useful feature. As all input data and output results were stored and processed within the same GIS environment, so the results could be easily visualized spatially using the data display and visualization capabilities of ArcGIS.

3. The design of a friendly graphic user interface made it possible to modify and calibrate the model quickly.

4. The accuracy assessment calibration of the model was also carried out in ArcGIS by comparing the model's simulation outcomes with actual urban scenarios.

The digital space in the CA consists of a rectangular grid of square cells $(100 \mathrm{~m} \times 100 \mathrm{~m})$. This is the same size as the minimum area mapped in urban areas in the land use datasets. All the data sets including the driving and constraints factors were also processed as regular spatial grids at a spatial scale of $100 \mathrm{~m}$. These data sets are used to feed the model to simulate the urban growth in the River Shannon Basin area.

Each cell was characterized by a vector of suitability parameters, one suitability for each land use taking part in the dynamics. The first suitability vector defines the weighted linear sum of a series of physical, environmental and institutional factors, characterizing each cell. The suitability parameters were normalized to values in the range of 0-1 (inclusive) using the fuzzy set memberships approach, and represent the inherent capacity of a cell to support a particular activity or land use. The second suitability vector was associated with the accessibility factors for each cell, again one for each land use type; these factors represent the importance of access to transportation networks, closest town and existing urban areas, for various land uses for each cell, again one for each land use type. Finally, for the third suitability vector each cell was associated with a set of codes representing its zoning status for various land uses, and for various periods. Due to the combined effect of suitability parameters, accessibilities, neighbourhood effect, and zoning, every cell is essentially unique in its qualities with respect to possible land uses. The suitability map was kept constant during the simulation process.

The model used five cell states, which were wetlands, water bodies, urban areas, agricultural areas and forest, the urban areas growth was the main focus in this study. Therefore, the classes that were considered as passive 
functions were: water bodies, wetlands, forest and agricultural. That was, functions that participate in the land use dynamics, but the dynamics were not driven by an exogenous demand for land; they appear or disappear in response to land being taken or abandoned by the active functions. The active function class was the urban area which was forced by demands for land generated exogenously to the cellular automaton in response to the growth of the urban area, it included Road and rail networks and associated land, Airports, Mineral extraction sites, Dump, Green urban areas, Sport and leisure facilities, continuous urban fabric, discontinuous urban fabric, sea port, Industrial and commercial and construction site.

During the modelling, the water bodies and wetlands growth were kept fixed features, these features were assumed to be converted to another land use type but does not grow in the future. The main reason behind this assumption was that during the change detection pattern analyses, the reduction of wetlands and water bodies over the years was noticed, therefore, these two features could not be assumed growing in the future, however, they still had an effect on the dynamics of the active land uses, since in the neighbourhood effect they may represent an attractive or repulsive effect.

With the concern that distortions may exist in a rectangular neighbourhood-type configuration ( $\mathrm{Li}$ and Yeh 2002), a circular neighbourhood was applied in this study. In the Cellular Automaton model, the neighbourhood space was defined as a circular region around the central cell with a radius of eight cells. The neighbourhood radius represented $0.8 \mathrm{~km}$; this distance delimits an area that can be defined as the influence area for urban land uses. That is similar to what residents of a town commonly identify to be their neighbourhood (Verburg et al. 2004a), and thus should be sufficient to allow spatial processes to be captured in the CA transition rules.

In the urban CA the neighbourhood space effect was calculated for each of the five function states (passive and active) for each cell. Essentially, this effect defines the state to which the cell could be converted or remains in their original state. The effect represents the attraction (positive) and repulsion (negative) effects of the various land uses and land covers within the neighbourhood of 172 cells in relation to the central cell. In general, cells that are more distant in the neighbourhood will have a smaller effect in the evaluated central cell. However, a positive weight of a cell on itself (zero-distance weight) represents an inertia effect due to the implicit and monetary costs of changing from one land use to another. (Barredo et al. 2003).

A vector of transition potential rules (one potential for each function) was calculated for each cell from transitional potential, dynamic constraints, elasticity of change and growth cells expectation, and the deterministic value was then given a stochastic perturbation using a modified extreme value distribution, such that most values are changed very little but a few are changed significantly:

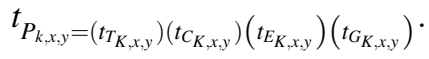

- ${ }^{t} \mathrm{P}_{\mathrm{K}, \mathrm{x}, \mathrm{y}}$ is the Cellular automata transition rule of the cell $(\mathrm{x}, \mathrm{y})$ for land use $\mathrm{K}$ at time $\mathrm{t}$.

- ${ }^{\mathrm{t}} \mathrm{T}_{\mathrm{K}, \mathrm{x}, \mathrm{y}}$ is transitional potential of the cell $(\mathrm{x}, \mathrm{y})$ for land use $\mathrm{K}$ at time $\mathrm{t}$.

- ${ }^{t} E_{K, x, y}$ is the change conversion probability value of the cell $(\mathrm{x}, \mathrm{y})$ for land use $\mathrm{K}$ at time $\mathrm{t}$.

- ${ }^{\mathrm{t}} \mathrm{C}_{\mathrm{K}, \mathrm{x}, \mathrm{y}}$ is the dynamic constraint value of cell $(\mathrm{x}, \mathrm{y})$ for land use $\mathrm{k}$ at time $\mathrm{t}$, which is basically the constraint land uses number that certain land use class is not allowed to change during the iteration processes.

- ${ }^{\mathrm{t}} \mathrm{G}_{\mathrm{K}, \mathrm{x}, \mathrm{y}}$ is the growth cells estimated for $(\mathrm{x}, \mathrm{y})$ for land use $\mathrm{K}$ at time $\mathrm{t}$.

Thus, the transition rule works to change each cell to the state for which it had the highest potential, subject to the related constrains. In every iteration, all cells were ranked by their highest potential and cell transitions begin with the highest ranked cell. At each iteration, each cell was subjected to this transition algorithm. However, most of the resulting transitions were from a state to itself, as a result the cell remained on its current state. When a transition to another state occurred, the actual transition to the second state occurred after one iteration (1 year) delay; during this interval the cell is assigned the state construction site.

It is important to mention the flexible way in which various factors that may impact the urban development in the Shannon River Basin area could be introduced into the CA model through the transition rules. The total impacts of the accelerating or constraining factors on the model's behaviour are explained as follows: if there is one accelerating/driving factor within the neighbourhood of the cell in question, the speed of urban development of that cell will be upgraded one step higher in the "speed" fuzzy set, however, if there is one constraining factor within the neighbourhood of the cell in question, the speed of urban development of the cell will be downgraded one step lower in the "speed" fuzzy set. If there is more than one such factor, the speed will be upgraded or downgraded two steps up or down. The existence of one accelerator and one constraint will cancel the effect of both factors; hence, the speed of development will stay unchanged.

The flexibility of the model enables it to function not only as an analytical tool to understand the forces driving the process of urban development but also as a planning tool to experiment with various planning proposals and 
generate different "what if" scenarios in the planning practice (Liu 2008).

In order to input the transition rules into the CA model, the Fuzzy Set Memberships (Liu and Phinn 2003) were used for all the driving factors maps, which means the values were converted from binary values to real numbers (0-1). The Fuzzy Set Memberships operation used in this study was monotonically decreasing to represent the decay effect, i.e. the closer the distance the better, so the closer the cell to any of the driving factors, the higher probability for it to change into urban land. Weighted raster values were given to each driving factor fuzzy map. This mechanism is intended to determine the influence of a factor towards a specific purpose of making a map of transitional potential units. The values of the weights were determined by simple priority values, which has been calibrated in the baseline period simulation by trial and error method (Table 5).

All driving-forces, after accumulated using weighted raster, were combined together with the protected area constraint map to have on transitional potential map. Determination of Conversion Probability was generated by overlaying two land use maps (2000 to 2006 and 2006 to 2012) using ArcGIS overlaying tool, and the conversion rate value of a certain land use changing to another land use was obtained (Table 6). Although the overlay method may not capture the phenomena that might occur, the two periods conversion values were obtained and compared to reach optimum conversion probability values. The growth of water bodies and wetlands were not considered in this study, but conversion probability was calculated for bother classes when overlaying.

Determination of Growth Cell was obtained using the simply trend analysis based on series of land use maps. The only dynamic constraint used in this study was with urban area not converting into water, wetlands and forest.

For each land use function, a vector of transition potential was calculated by combining the transitional potential, dynamic constraints, elasticity of change and

Table 5 Raster weighted values used for the urban area land use class

\begin{tabular}{ll}
\hline Fuzzy driving factors & Weighted raster values \\
\hline Distance to minor roads & 0.12 \\
Distance to major roads & 0.12 \\
Distance to town/cities & 0.2 \\
Distance to existing urban area & 0.2 \\
Distance to high population area & 0.15 \\
Distance to medium population area & 0.11 \\
Distance to small population area & 0.1 \\
\hline
\end{tabular}

growth cells expectation mentioned above. All the above steps were done using LanduseSim software (Pratomoatmojo 2016; Ratriaga and Sardjito 2016; Pratomoatmojo 2012), which is implemented using a CA model; the general model framework is illustrated in Fig. 12.

The fuzzy constrained CA model developed in this study was configured temporally when applying it to simulate the process of urban growth in River Shannon Basin area. For the validation of the model, the starting date was set to 2000, and the ending date to 2006. Each temporal advance of the model represents one year in the urban growth context. Data illustrating the urban extent within the simulation period at every 6-year interval were used to calibrate the model temporally. The main reason for choosing the 6-year interval was the land cover maps used in the validation process were obtained from the Irish EPA, and they were available in 6-year intervals, 2000, 2006 and 2012.

\section{Model calibration and validation}

A land use simulation for the River Shannon Basin area had been produced for the period 2000-2012 using the urban CA model. The simulation began using the historical datasets for the year 2000, in order to calibrate the simulation results using the reference datasets for the year 2006. Afterward, the model was simulated for the year 2012 and comparison with the actual land cover was also made for validation purposes.

The validation of the model was carried out over the period 2000-2012 using the land use datasets. The present simulations make no use of suitabilities or zoning, since these data are not yet available. The preliminary results are a useful demonstration of the extent to which the urban CA can produce realistic simulations using the available data.

Based on the configuration comprising a cell size of $100 \mathrm{~m}$ and a circular neighbourhood with a radius of eight cells, the model of urban development of River Shannon Basin area was first implemented with the primary transition rules that had the first weighting parameter assumption for the driving factors, the zoning protected areas constrains, the conversion probability values and the growth cells estimation obtained from the overlaying of the land cover maps. Subsequently, the secondary transition rules were introduced into the model after changing the weighting parameters and conversion probability to calibrate the model and evaluate its simulation accuracies using the previous stat of urban development from 2000 to 2006 and from 2000 to 2012 as references for comparison. The transition rules were introduced in the model based on the sequence of physical constraints, socio-economic factors, and institutional controls. 
Table 6 Transition probability matrix calculated using land-use maps 2000-2006 and 2006-2012

\begin{tabular}{llllll}
\hline Land Cover Classes & Water bodies & Wetlands & Urban area & Agricultural & Forest \\
\hline Water bodies & 0 & 0.19 & 0.01 & 0.64 & 0.16 \\
Wetlands & 0.03 & 0 & 0.00 & 0.39 & 0.57 \\
Urban area & 0.01 & 0.02 & 0 & 0.87 & 0.11 \\
Agricultural & 0.03 & 0.36 & 0.02 & 0 & 0.58 \\
Forest & 0.01 & 0.45 & 0.00 & 0.54 & 0 \\
\hline
\end{tabular}

\section{Identification of factors}

Primary Road Networks Secondary Road Networks Central Business District etc

Land Use Simulation Result

Weighting and Overlay

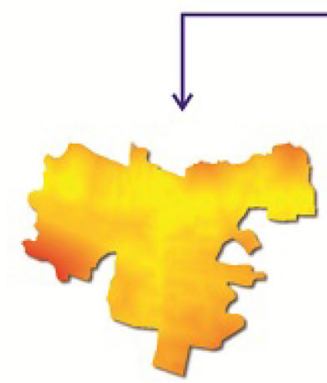

Suitability Map

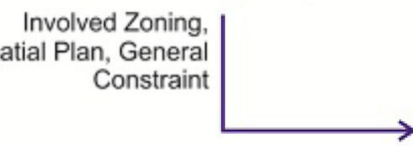

Set of Transition Rules

Concequences, Hierarchy, Dynamic Constraint, Suitability, Conversion Probability

Neighborhood Filter

Filter Shape, Filter Weight, Filter Operation

\section{Time-Step Operation}

Number of Iteration, Time-Series of Output Maps

Fig. 12 General model framework (Pratomoatmojo 2016)

The weighting parameters were calibrated in order to minimise the differences between the simulated land use map for 2006 and the actual land use map for that year. From a practical point of view, the calibration of the model was based on an interactive procedure in which each state (active and passive) was calibrated against each of the land uses classes. The weighting parameters were thus assigned for each driving factor through interactive windows incorporated in the software prototype and then assigned to each land use. The weighting assignment was done by verifying visually the spatial effects of the weights in the CA model. Once all the functions have been calibrated, the model is re-run several times in order to verify if the land use transitions work in a logical way. Another important factor for the calibration of the model was the conversion probability values. The values were obtained by overlaying the land cover maps for the periods 2000 to 2006, but after simulation the model several times, it was noticed that some of the land use conversion trends were not captured by the model, therefore the overlaying values from 2006 to 2012 land cover were also considered and an optimum conversion probability values were use. Comparison matrices were also used for producing a fine-tuned version of the simulation which gave accurate and realistic results.

By varying the parameters of the transition rules within each iteration of the model and changing the balance between the rules, various simulation results were produced, and their accuracies against the land cover of the River Shannon Basin area at every 6-year interval were computed using the modified error matrix approach. Figure 13 shows the various simulation accuracies of the model under all transition rules over time.

The assessment of error in CA modelling is important for understanding the results of simulation. The actual land cover map was overlaid with the simulation map to identify the accuracy for the five land use classes; the values 


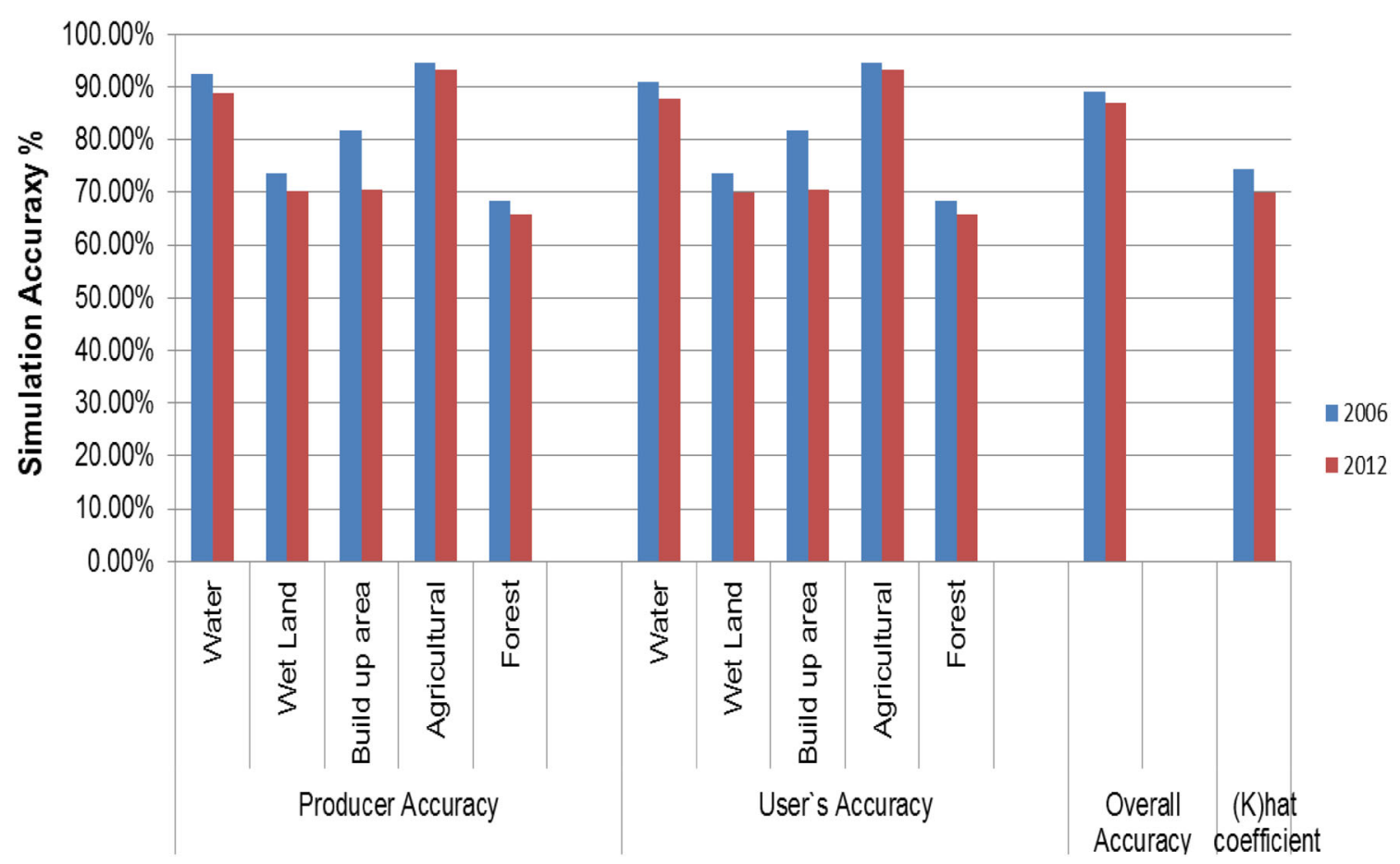

Fig. 13 The model's simulation accuracies under all transition rules over time (2006-2012)

Table 7 Definitions of terms used in an error matrix and their computations

\begin{tabular}{|c|c|c|}
\hline Terms & Description & Computations \\
\hline $\begin{array}{r}\text { Producer's } \\
\text { accuracy }\end{array}$ & $\begin{array}{l}\text { Probability of reference cells being correctly categorised in the } \\
\text { classification data. This measures the omission error }\end{array}$ & $\begin{array}{l}\text { Number of cells on the major diagonal divided by } \\
\text { the column total of each category }\end{array}$ \\
\hline $\begin{array}{l}\text { User`s } \\
\text { accuracy }\end{array}$ & $\begin{array}{l}\text { Probability that cells in the classification data actually belongs to the same } \\
\text { category as in the reference data. This measures the commission error }\end{array}$ & $\begin{array}{l}\text { Number of cells on the major diagonal divided by } \\
\text { the row total of each category }\end{array}$ \\
\hline $\begin{array}{l}\text { Omission } \\
\text { error }\end{array}$ & $\begin{array}{l}\text { Cells that are excluded (omitted) from the categories that they belong to in } \\
\text { the reference data }\end{array}$ & $\begin{array}{l}\text { Total of the off-diagonal column cells divided by } \\
\text { the column total of each category }\end{array}$ \\
\hline $\begin{array}{l}\text { Commission } \\
\text { error }\end{array}$ & $\begin{array}{l}\text { Cells that are included (committed) in the categories that they do not } \\
\text { belong to in the reference data }\end{array}$ & $\begin{array}{l}\text { Total of the off-diagonal row cells divided by the } \\
\text { row total of each category }\end{array}$ \\
\hline $\begin{array}{l}\text { Overall } \\
\text { accuracy }\end{array}$ & $\begin{array}{l}\text { A measurement of the overall proportion of correctly categorised cells in } \\
\text { relation to the total number of cells under assessment }\end{array}$ & $\begin{array}{l}\text { Total number of cells along the major diagonal of } \\
\text { the matrix divided by the total number of cells }\end{array}$ \\
\hline
\end{tabular}

represent percentage between the simulated and actual number of cells at the resolution of $100 \mathrm{~m}$. A visual comparison of the model's simulated results with actual land cover of the River Shannon Basin from 2006 to 2012 showed that, in general, results produced by the model matched well with the actual urban extent over these time periods. The model was well able to capture the spatial patterns of urban area, especially for the year 2006. The calibration of the model over time enables the model to simulate with high accuracy the changes in land use: the overall accuracy for 2006 was of $89.01 \%$ and for 2012 of $87.09 \%$.

The results accuracy of the model is considered significant given that the model only incorporated limited factors that contribute to the actual urban development of River Shannon Basin area. Other factors such as the accessibility to nodes of employment and other services, and facilities such as schools, shops, etc., that may also have affected the process of the River Shannon Basin area's urban development had not been introduced into the model due to difficulties in data collection.

However, the producer's and user's accuracies (Table 7) for the error terms definitions of each category show that large discrepancies exist between the simulated results and the land cover in the forest category, resulting in lower accuracies from both the producer's and user's perspectives. For instance, the producer's and user's accuracies for the forest category in 2006 were only $68.32 \%$. This means 
Table 8 Land cover transition matrix of River Shannon Basin area

\begin{tabular}{lrr}
\hline Land cover classes & $\mathrm{km}^{2}$ & Percent \\
\hline Change 2012-2020 & & \\
Water bodies & -1.71 & -0.39 \\
Wetlands & -208.45 & -11.51 \\
Urban area & 28.53 & 9.75 \\
Agricultural & 110.99 & 0.82 \\
Forest & 70.64 & 3.11 \\
Change 2012-2050 & & \\
Water bodies & -1.71 & -0.39 \\
Wetlands & -208.45 & -11.51 \\
Urban area & 28.53 & 9.75 \\
Agricultural & 110.99 & 0.82 \\
Forest & 70.64 & 3.11 \\
Change 2012-2080 & & \\
Water bodies & -1.71 & -0.39 \\
Wetlands & -208.45 & -11.51 \\
Urban area & 28.53 & 9.75 \\
Agricultural & 110.99 & 0.82 \\
Forest & 70.64 & 3.11 \\
\hline
\end{tabular}

that $31.68 \%$ of the actual forest areas were omitted from being selected for development, and $32.68 \%$ of the simulated forest areas were committed to the category by the model incorrectly. In addition, for the same forest category, the producer's and user's accuracy in 2012 were also low. This is also reflected in the model's results showing a lower percentage of $68.32 \%$ of forest areas in 2006 and $65.68 \%$ in 2012 compared to all other classes which are above $70 \%$. This is largely due to the fact that the forest areas only consist of approximately $12 \%$ of the total area of the River Shannon Basin area; therefore, even a small amount of mismatched cells between the actual urban extent and the simulated results would result in a high percentage of discrepancy between the two data sets, and hence, lower the producer's and user's accuracies in this category.

For the fully urban area, because $1.36 \%$ of the River Shannon Basin area had already been fully urbanised at the start of the model in 2000, and these fully urban areas remain as urban during the whole simulation process, the actual composition of fully urban areas has only increased to $1.55 \%$ in 2006 and to $1.59 \%$ in 2012 . However, all urban cells including those that did not change states during the simulation process were counted when computing the simulation accuracies of the model for the fully urban category. This reduces the impact of the mismatched cells on both the producer's and user's accuracies for the fully urban category. The producer's and user's accuracy for the urban areas in 2006 was $81.76 \%$. This means that $18.24 \%$ of the actual urban areas were omitted from being selected for development, and $18.24 \%$ of the simulated urban areas were committed to the category by the model incorrectly. In addition, for the same urban area category, the producer's and user's accuracy in 2012 were $70.50 \%$.

The total number of cell in each grid was around 40,000 cell. In 2006, in the urban area simulation class, 4462 cells were incorrectly assigned as agricultural areas. On the other hand, 604 cells were incorrectly assigned to forest and 60 cells were incorrectly assigned by the simulation to water bodies. Also 83 cells were incorrectly assigned to wetlands during the simulation. In 2012, 116 cells were incorrectly assigned as waters bodies and wetlands rather than urban areas. On the other hand, 7665 cells were incorrectly assigned to Agricultural and 740 cells were incorrectly assigned by the simulation to forest instead of urban areas.
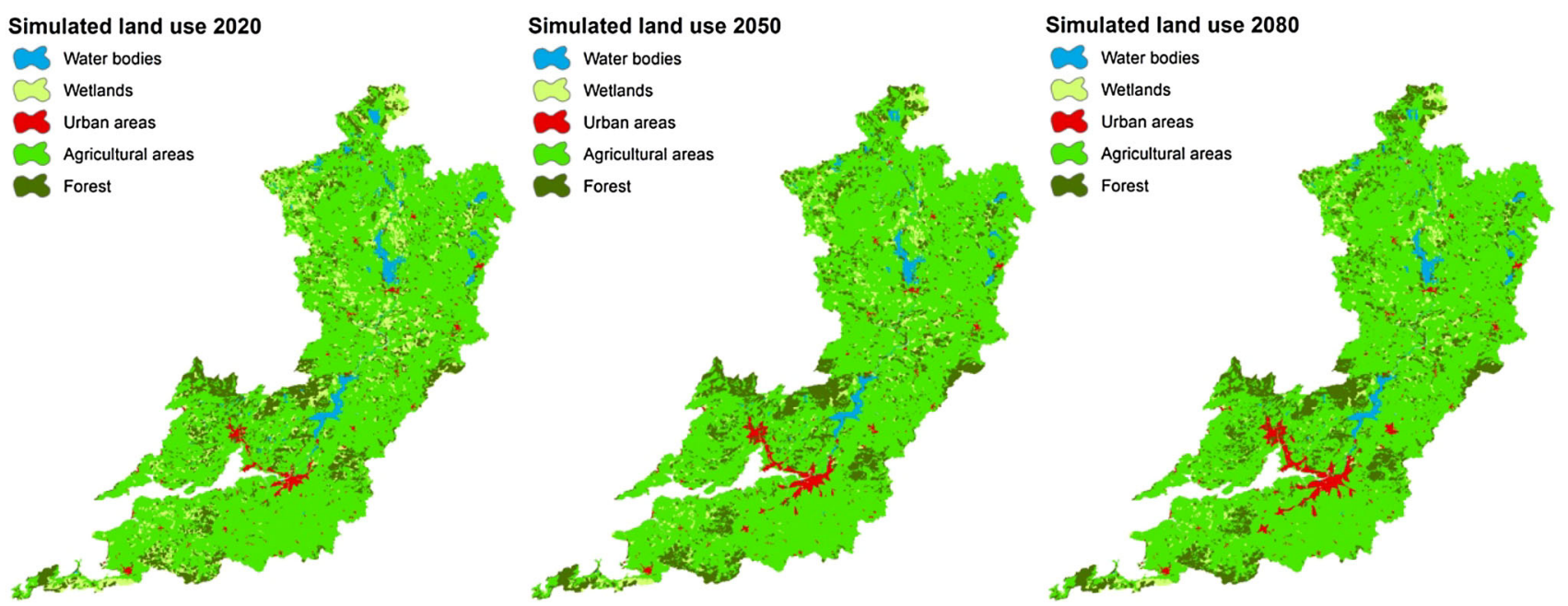

Fig. 14-16 Cellular automata (CA) predicted land cover for 2020, 2050 and 2080 
Due to the transition rules of CA model, such rules can in effect evenly locate new urban cells mainly in the city core and around the edge of initial urban areas. As a result, some of simulated urban cells in the city core were located where no changes from non-urban to urban land uses took place. While some real developed cells were underestimated by models. The errors found in simulation results also reveal that some errors were caused by issues not related to the model, such as the complexity of urban growth. Urban expansion process usually has some unpredictable features because of the complexity of nature.

\section{Results and discussions}

The combination of the different parameters and the calibrated model were used to produce a series of maps showing the future scenarios for the River Shannon Basin area for the years 2020, 2050 and 2080 in order to use them later in water balance simulations.

The results of land cover conversions of the Shannon River Basin area in 2020 were compared to land cover in 2012, the comparison of change detection was carried out using GIS, producing matrices of land cover changes. The statistics generated in the matrices is "from-to" information for the study area, they revealed few insights into the question of where land cover changes will be occurring.

The results for the Shannon Basin area (Table 8) indicate an increase of urban area from $1.59 \%$ in 2012 to $1.75 \%$ in 2020 , which is a total of $28.53 \mathrm{~km}^{2}$ of land will be converted into urban areas in 2020. That means the overall change percentage from 2012 to 2020 will be $9.75 \%$. The majority of the urban area will come from the conversion of agricultural to urban areas; also, the small portion of the increase will be from converting wetlands and forest to urban area. That increase will depend on the economy growth of Ireland up to 2020. Rapid development requires more built-up land and industrial workers, which will also lead to relatively high urbanization speed. The incredible pressure of rapid urbanization on non-urban land will be reflected by the high loss of agricultural and forest land. Figure 14 shows the urban expansion will be mainly around Limerick city, Ennis, Mullingar, Athlone, Tralee, Cratloe, Clareabbey, Tullamore, Longford, and Rosecommon rural (Fig. 14).

Also, there will be an increase in forest land from $12.37 \%$ in 2012 to $12.75 \%$ in 2020 , which is $70.64 \mathrm{~km}^{2}$ with an overall change percentage of $3.11 \%$. The analysis showed that forest cover will increase at the expense of wetlands and agricultural areas mainly. Moreover, there will be a gradual increase in agricultural areas from $73.79 \%$ in 2012 to $74.40 \%$ in 2020 , which is a total of $110.99 \mathrm{~km}^{2}$ of land will be converted into urban agricultural areas in 2020. That means the overall change percentage from 2012 to 2020 will be $0.82 \%$. The agricultural areas will increase at the expense of wetlands and forest cover mainly.

Due to the increase of urban areas, forest and agricultural covers, there will be a reduction in wetlands and water bodies in 2020 , with a decrease of $208.45 \mathrm{~km}^{2}$ and $1.71 \mathrm{~km}^{2}$ of wetlands and water bodies respectively. The wetlands will decrease from $9.85 \%$ in 2012 to $8.72 \%$ in 2020 , with an overall change of $-11.51 \%$. While the water bodies will decrease from $2.39 \%$ in 2012 to $2.38 \%$ in 2020 with an overall change of $-0.39 \%$. Figure 14 and Table 8 show River Shannon Basin area predicated map and percentages in 2020 .

The results of land cover conversions of the Shannon River Basin area in 2050 were compared to land cover in 2012, the comparison of change detection was carried out using GIS, producing matrices of land cover changes. The results for the Shannon Basin area indicate an increase of urban area from $1.59 \%$ in 2012 to $2.34 \%$ in 2050, which is a total $136.38 \mathrm{~km}^{2}$ of land will be converted into urban areas in 2050 (Table 8). That means the overall change percentage from 2012 to 2050 will be $46.59 \%$. The majority of the urban area will come from the conversion of agricultural to urban areas; also, the small portion of the increase will be from converting wetlands and forest to urban area. That increase will depend on the economy growth of Ireland up to 2050. Rapid development requires more built-up land and industrial workers, which will also lead to relatively high urbanization speed. The incredible pressure of rapid urbanization on non-urban land will be reflected by the high loss of agricultural and forest land. Figure 15 shows the urban expansion will be mainly around Limerick city, Ballyvarra, Ballycummin, Patrickswell (in County Limerick), Mullingar, Athlone (County Westmeath), Tralee (County Kerry), Ennis Cratloe, Clareabbey, Ballyglass, Clenagh, Drumline, Newmarket, Urlan (in County Clare) Tullamore (County offaly), longford (County longford) and Rosecommon rural (County Rosecommon) and Nenagh (County Tipperary).

Also, there will be an increase in forest land from $12.37 \%$ in 2012 to $14.18 \%$ in 2050 , which is $332.94 \mathrm{~km}^{2}$ with an overall change percentage of $14.66 \%$. The analysis showed that forest cover will increase at the expense of wetlands and agricultural areas mainly and small portion of water bodies. Moreover, there will be a gradual increase in agricultural areas from $73.79 \%$ in 2012 to $76.81 \%$ in 2050 , which is a total of $553.59 \mathrm{~km}^{2}$ of land will be converted into urban agricultural areas in 2050. That means the overall change percentage from 2012 to 2050 will be $4.08 \%$. The agricultural areas will increase at the expense of wetlands and forest cover mainly and small portion of water bodies. 
Due to the increase of urban areas, forest and agricultural covers, there will be a reduction in wetlands and water bodies in 2050, with a decrease of $941.21 \mathrm{~km}^{2}$ and $81.7 \mathrm{~km}^{2}$ of wetlands and water bodies respectively. The wetlands will decrease from $9.85 \%$ in 2012 to $4.73 \%$ in 2050 , with an overall change of $-51.99 \%$. While the water bodies will decrease from $2.39 \%$ in 2012 to $1.95 \%$ in 2050 with an overall change of $-18.58 \%$. Figure 15 and Table 8 show River Shannon Basin area predicated map and percentages in 2050.

The results of land cover conversions of the Shannon River Basin area in 2080 were compared to land cover in 2012, the comparison of change detection was carried out using GIS, producing matrices of land cover changes. The results for the Shannon Basin area indicate an increase of urban area from $1.59 \%$ in 2012 to $2.92 \%$ in 2080, which is a total $244.05 \mathrm{~km}^{2}$ of land will be converted into urban areas in 2080. That means the overall change percentage from 2012 to 2080 will be $83.37 \%$. The majority of the urban area will come from the conversion of agricultural to urban areas; also, the small portion of the increase will be from converting wetlands and forest to urban area. That increase will depend on the economy growth of Ireland up to 2080. Rapid development requires more built-up land and industrial workers, which will also lead to relatively high urbanization speed. The incredible pressure of rapid urbanization on non-urban land will be reflected by the high loss of agricultural and forest land. Figure 16 shows the urban expansion will be mainly around Limerick city, Ballyvarra, Ballycummin, Patrickswell, Newcastle urban, Ranthkeale urban, Croom, Ballysimon, Ballynanty (Co. Limerick), Mullingar, Athlone (County Westmeath) Tralee (County Kerry), Ennis, Cratloe, Clareabbey, Ballyglass, Clenagh, Drumline, Newmarket, Urlan, Templemaley, Kilnamona (in County Clare) Tullamore (County Offaly), Longford (County Longford), Rosecommon Rural (County Rosecommon) and Nenagh (County Tipperary).

Also, there will be an increase in forest land from $12.37 \%$ in 2012 to $14.62 \%$ in 2080, which is $414.13 \mathrm{~km}^{2}$ with an overall change percentage of $18.23 \%$. The analysis showed that forest cover will increase at the expense of wetlands and agricultural areas mainly and small portion of water bodies. Moreover, there will be a gradual increase in agricultural areas from $73.79 \%$ in 2012 to $76.28 \%$ in 2050 , which is a total of $456.42 \mathrm{~km}^{2}$ of land will be converted into urban agricultural areas in 2080. That means the overall change percentage from 2012 to 2080 will be $3.37 \%$. The agricultural areas will increase at the expense of wetlands and forest cover mainly and small portion of water bodies.

Due to the increase of urban areas, forest and agricultural covers, there will be a reduction in wetlands and water bodies in 2080, with a decrease of $1024.49 \mathrm{~km}^{2}$ and
$90.11 \mathrm{~km}^{2}$ of wetlands and water bodies respectively. The wetlands will decrease from $9.85 \%$ in 2012 to $4.28 \%$ in 2080 , with an overall change of $-56.59 \%$. While the water bodies will decrease from $2.39 \%$ in 2012 to $1.90 \%$ in 2080 with an overall change of $-20.50 \%$. Figure 16 and Table 8 show River Shannon Basin area predicated map and percentages in 2080 .

\section{Conclusions and limitations}

This paper presented a simulation model of urban development and land use change using the CA approach incorporating fuzzy set theories and spatial information technology. Through the development of the model, the study contributes to the integration of CA modelling and GIS for urban development research.

It has been confirmed in this study that the weakness of CA model was the assumption of spatial and temporal invariance for transition rules and the inability of CA to deal with stochastic behaviour (Couclelis 1985). The transition rules could not include conflict-resolving rules in the model (Jiao and Boerboom 2006). It was confirmed, as previously demonstrated by (Twumasi 2008) that CA examines the synchronous dynamics of urban environment, in essence all cells update simultaneously at each iterative step, which means the cells were simply changed to the function to which they have the highest potential in terms of the factors modelled. But real cities are chaotic in their behaviour, therefore other factors may contribute to deciding on the final locations of cells and simply changing cells to the highest potential may not be sufficient. Unlike many natural processes to which CA algorithms had been applied, land uses do not mutate autonomously. The prediction results for the Shannon Basin area indicate an increase of urban area from $1.59 \%$ in 2012 to $1.75 \%$ in 2020 , which is a total of $28.53 \mathrm{~km}^{2}$ of land will be converted into urban areas in 2020 . That means the overall change percentage from 2012 to 2020 will be $9.75 \%$. The results for the Shannon Basin area indicate an increase of urban area from $1.59 \%$ in 2012 to $2.34 \%$ in 2050, which is a total $136.38 \mathrm{~km}^{2}$ of land will be converted into urban areas in 2050 .

The results for the Shannon Basin area indicate an increase of urban area from $1.59 \%$ in 2012 to $2.92 \%$ in 2080 , which is a total $244.05 \mathrm{~km}^{2}$ of land will be converted into urban areas in 2080. That means the overall change percentage from 2012 to 2080 will be $83.37 \%$. The majority of the urban area will come from the conversion of agricultural to urban areas; also, the small portion of the increase will be from converting wetlands and forest to urban area. The urban expansion will be mainly around Limerick city, Ennis, Mullingar, Athlone and Tipperary. 
As a novel land use modelling technique, the integrated CA-GIS enriched the theories and methods of CA by addressing the complex boundaries of land use extent. However, limitations of this method also existed because the CA method was relatively complex in its theory and calculation mechanisms. This method needed an understanding of the mechanisms of land use dynamics in addition to the mathematical and computer technologies. This paper presented as a novel application to the integrated CA-GIS model using a complicated land use dynamic system for Shannon catchment.

Acknowledgments This research was funded by Trinity College, 651 Dublin through Postgraduate Ussher Fellowship Award.

\section{References}

Balzter H, Braun PW, Köhler W (1998) Cellular automata models for vegetation dynamics. Ecol Model 107:113-125

Barredo JI, Kasanko M, McCormick N, Lavalle C (2003) Modelling dynamic spatial processes: simulation of urban future scenarios through cellular automata. Landsc Urban Plan 64:145-160

Batty M (1998) Urban evolution on the desktop: simulation with the use of extended cellular automata. Environ Plan A 30:1943-1967

Batty M, Xie Y, Sun Z (1999) Modeling urban dynamics through GIS-based cellular automata. Comput Environ Urban Syst 23:205-233

Buss TF (2001) The effect of state tax incentives on economic growth and firm location decisions: an overview of the literature. Econ Dev Q 15:90-105

Caruso G, Rounsevell M, Cojocaru G (2005) Exploring a spatiodynamic neighbourhood-based model of residential behaviour in the Brussels periurban area. Int J Geogr Inf Sci 19:103-123

Chen Q, Mynett AE (2003) Effects of cell size and configuration in cellular automata based prey-predator modelling. Simul Model Pract Theory 11:609-625

Chen M, Lu D, Zha L (2010) The comprehensive evaluation of China's urbanization and effects on resources and environment. J Geog Sci 20:17-30

Cho H, Swartzlander EE (2007) Adder designs and analyses for quantum-dot cellular automata. Nanotechnol IEEE Trans $6: 374-383$

Clarke KC, Gaydos LJ (1998) Loose-coupling a cellular automaton model and GIS: long-term urban growth prediction for San Francisco and Washington/Baltimore. Int $\mathrm{J}$ Geogr Inf Sci 12:699-714

Clarke KC, Hoppen S, Gaydos L (1997) A self-modifying cellular automaton model of historical urbanization in the San Francisco Bay area. Environ Plan 24:247-261

Cohen B (2004) Urban growth in developing countries: a review of current trends and a caution regarding existing forecasts. World Dev 32:23-51

Coppin P, Jonckheere I, Nackaerts K, Muys B, Lambin E (2004) Review ArticleDigital change detection methods in ecosystem monitoring: a review. Int J Remote Sens 25:1565-1596

Couclelis H (1985) Cellular worlds: a framework for modeling micro-macro dynamics. Environ Plan A 17:585-596

Couclelis H (2000) From sustainable transportation to sustainable accessibility: can we avoid a new tragedy of the commons? In: Janelle DG, Hodge DC (eds) Information, place, and cyberspace.
Advances in spatial science, Part IV. Springer, Berlin, Heidelberg, pp 341-356

Defries RS, Rudel T, Uriarte M, Hansen M (2010) Deforestation driven by urban population growth and agricultural trade in the twenty-first century. Nat Geosci 3:178-181

Deutsch A, Dormann S (2007) Cellular automaton modeling of biological pattern formation: characterization, applications, and analysis. Springer Science and Business Media, Berlin

Du H, Mulley C (2006) Relationship between transport accessibility and land value: local model approach with geographically weighted regression. Transp Res Rec J Transp Res Board 197-205

EPA (2012) Environmental Protection Agency (EPA) [Online]. Available: http://www.epa.ie/soilandbiodiversity/soils/land/cor ine/\#.VbjfhflViko. Accessed 15 Feb 2015

EPA (2015) Corine Land Cover Mapping, EPA [Online]. Environmental Agency Protection (EPA) Available: http://www.epa.ie/ soilandbiodiversity/soils/land/corine/\#.Vbo-2_1Viko. Accessed 20 Jun 2015

Evans D (2006) The habitats of the European Union habitats directive. In: Biology and environment: Proceedings of the Royal Irish Academy, 2006. JSTOR, pp 167-173

Flache A, Hegselmann R (2001) Do irregular grids make a difference? Relaxing the spatial regularity assumption in cellular models of social dynamics. J Artif Soc Soc Simul 4(4)

Foley JA, Defries R, Asner GP, Barford C, Bonan G, Carpenter SR, Chapin FS, Coe MT, Daily GC, Gibbs HK, Helkowski JH, Holloway T, Howard EA, Kucharik CJ, Monfreda C, Patz JA, Prentice IC, Ramankutty N, Snyder PK (2005) Global consequences of land use. Science 309:570-574

Geertman S, Hagoort M, Ottens H (2007) Spatial-temporal specific neighbourhood rules for cellular automata land-use modelling. Int J Geogr Inf Sci 21:547-568

Geurs KT, van Wee B (2004) Accessibility evaluation of land-use and transport strategies: review and research directions. J Transp Geogr 12:127-140

Gharbia SS, Gill L, Johnston P, Pilla F (2015) GEO-CWB: a dynamic water balance tool for catchment water management. In: 5th international multidisciplinary conference on hydrology and ecology (HydroEco2015), at Vienna, Austria, 2015

Gharbia SS, Gill L, Johnston P, Pilla F (2016a) Multi-GCM ensembles performance for climate projection on a GIS platform. Model Earth Syst Environ 2:1-21

Gharbia SS, Gill L, Johnston P, Pilla F (2016b) Using GIS based algorithms for GCMs' performance evaluation. In: 18th IEEE mediterranean electrotechnical conference MELECON 2016. IEEE, Cyprus

Herold M, Goldstein NC, Clarke KC (2003) The spatiotemporal form of urban growth: measurement, analysis and modeling. Remote Sens Environ 86:286-302

Herold M, Couclelis H, Clarke KC (2005) The role of spatial metrics in the analysis and modeling of urban land use change. Comput Environ Urban Syst 29:369-399

Iovine G, D'Ambrosio D, di Gregorio S (2005) Applying genetic algorithms for calibrating a hexagonal cellular automata model for the simulation of debris flows characterised by strong inertial effects. Geomorphology 66:287-303

Itami RM (1994) Simulating spatial dynamics: cellular automata theory. Landsc Urban Plan 30(1-2):27-47

Jantz CA, Goetz SJ, Shelley MK (2004) Using the SLEUTH urban growth model to simulate the impacts of future policy scenarios on urban land use in the Baltimore-Washington metropolitan area. Environ Plan 31:251-271

Jenerette GD, Wu J (2001) Analysis and simulation of land-use change in the central Arizona-Phoenix region, USA. Landsc Ecol 16:611-626 
Jiao J, Boerboom L (2006) Transition rule elicitation methods for urban cellular automata models. In: Van Leeuwen J, Timmermans HP (eds) Innovations in design and decision support systems in architecture and urban planning. Springer, Netherlands

Jokar Arsanjani J, Helbich. M, Kainz W, Darvishi Boloorani A (2013) Integration of logistic regression, Markov chain and cellular automata models to simulate urban expansion. Int J Appl Earth Obs Geoinf 21:265-275

Kueppers L, Baer P, Harte J, Haya B, Koteen L, Smith M (2004) A decision matrix approach to evaluating the impacts of land-use activities undertaken to mitigate climate change. Clim Chang 63:247-257

Lambin EF (1997) Modelling and monitoring land-cover change processes in tropical regions. Prog Phys Geogr 21:375-393

Lau KH, Kam BH (2005) A cellular automata model for urban landuse simulation. Environ Plan 32:247-263

Li C (2014) Monitoring and analysis of urban growth process using remote sensing, GIS and cellular automata modeling: a case study of Xuzhou city. TU Dortmund University, China

Li X, Yeh AG-O (2000) Modelling sustainable urban development by the integration of constrained cellular automata and GIS. Int $\mathrm{J}$ Geogr Inf Sci 14:131-152

Li X, Yeh G-O (2002) Integration of principal components analysis and cellular automata for spatial decisionmaking and urban simulation. Sci China, Ser D Earth Sci 45:521-529

Li W, Packard NH, Langton CG (1990) Transition phenomena in cellular automata rule space. Phys D 45:77-94

Li X, Zhou W, Ouyang Z (2013) Forty years of urban expansion in Beijing: what is the relative importance of physical, socioeconomic, and neighborhood factors? Appl Geogr 38:1-10

Liu Y (2008) Modelling urban development with geographical information systems and cellular automata. CRC Press (Taylor \& Francis Group), London

Liu Y, Phinn SR (2003) Modelling urban development with cellular automata incorporating fuzzy-set approaches. Comput Environ Urban Syst 27:637-658

Liu Y, HE J (2009) Developing a web-based cellular automata model for urban growth simulation. In: International symposium on spatial analysis, spatial-temporal data modeling, and data mining, 2009. International Society for Optics and Photonics, 74925C-74925C-8

Liu J, Zhan J, Deng X (2005) Spatio-temporal patterns and driving forces of urban land expansion in China during the economic reform era. AMBIO J Hum Environ 34:450-455

Liu X, Li X, Liu L, He J, Ai B (2008) A bottom-up approach to discover transition rules of cellular automata using ant intelligence. Int J Geogr Inf Sci 22:1247-1269

Lu D, Weng Q (2004) Spectral mixture analysis of the urban landscape in Indianapolis with Landsat ETM + imagery. Photogramm Eng Remote Sens 70:1053-1062

M'nard A, Marceau DJ (2005) Exploration of spatial scale sensitivity in geographic cellular automata. Environ Plan 32:693-714

Malczewski J (2004) GIS-based land-use suitability analysis: a critical overview. Prog Plan 62:3-65

May RM (1976) Simple mathematical models with very complicated dynamics. Nature 261:459-467

Meyer WB, Turner BL (1992) Human population growth and global land-use/cover change. Annu Rev Ecol Syst 23:39-61

Miller HJ (1999) Measuring space-time accessibility benefits within transportation networks: basic theory and computational procedures. Geogr Anal 31:1-26

Munshi T, Zuidgeest M, Brussel M, van Maarseveen M (2014) Logistic regression and cellular automata-based modelling of retail, commercial and residential development in the city of Ahmedabad, India. Cities 39:68-86
Pijanowski BC, Brown DG, Shellito BA, Manik GA (2002) Using neural networks and GIS to forecast land use changes: a land transformation model. Comput Environ Urban Syst 26:553-575

Portugali J, Benenson I (1995) Artificial planning experience by means of a heuristic cell-space model: simulating international migration in the urban process. Environ Plan A 27:1647-1665

Pratomoatmojo NA (2012) Land use change modelling under tidal flood scenario by means of Markov-cellular automata in Pekalongan municipal. Universitas Gadjah Mada,Yogyakarta

Pratomoatmojo NA (2016) LanduseSimPractice: spatial modeling of settlement and industrial growth by means of cellular automata and Geographic Information System. Urban and Regional Planning Department, Sepuluh Nopember Institute of Technology, Surabaya

Preston SH (1979) Urban growth in developing countries: a demographic reappraisal. Popul Dev Rev, pp 195-215

Ratriaga ARN, Sardjito S (2016) Penentuan Rute Angkutan Umum Optimal Dengan Transport Network Simulator (TRANETSIM) di Kota Tuban. J Tek ITS 4:C87-C91

Reilly MK, O'Mara MP, Seto KC (2009) From Bangalore to the Bay Area: comparing transportation and activity accessibility as drivers of urban growth. Landsc Urban Plan 92:24-33

Reinau KH (2006) Cellular automata and urban development. In: Nordic GIS conference, 2006, pp 75-80

Rietveld P, Bruinsma F (2012) Is transport infrastructure effective?: transport infrastructure and accessibility: impacts on the space economy. Springer Science and Business Media, Berlin

Rounsevell M, Reginster I, Araújo MB, Carter T, Dendoncker N, Ewert F, House J, Kankaanpää S, Leemans R, Metzger M (2006) A coherent set of future land use change scenarios for Europe. Agric Ecosyst Environ 114:57-68

Serneels S, Lambin EF (2001) Impact of land-use changes on the wildebeest migration in the northern part of the Serengeti-Mara ecosystem. J Biogeogr 28:391

Shahumyan H, Twumasi BO, Convery S, Foley R, Vaughan E, Casey E, Carty J, Walsh C, Brennan M (2009) Data preparation for the MOLAND model application for the greater Dublin region. UCD Urban Institute Ireland, Working Paper Series

Shi W, Pang MYC (2000) Development of Voronoi-based cellular automata-an integrated dynamic model for Geographical Information Systems. Int J Geogr Inf Sci 14:455-474

Sim LK, Balamurugan G (1991) Urbanization and urban water problems in Southeast Asia a case of unsustainable development. J Environ Manag 32:195-209

Simmie J, Martin R (2010) The economic resilience of regions: towards an evolutionary approach. Cambridge J Reg Econ Soc 3:27-43

Singh A (1989) Review Article Digital change detection techniques using remotely-sensed data. Int J Remote Sens 10:989-1003

Takeyama M, Couclelis H (1997) Map dynamics: integrating cellular automata and GIS through Geo-Algebra. Int J Geogr Inf Sci 11:73-91

Tobler WR (1979) Cellular geography. In: Gale S, Olsson G (eds) Philosophy in geography. Reidel Publishing Company, Dordrecht, Holland, pp 379-386

Torrens PM (2000) How cellular models of urban systems work (1. Theory). CASA Working Papers 28. Centre for Advanced Spatial Analysis (UCL), London, UK

Twumasi BO (2008) Recommendations for further improvement to the MOLAND model. UCD Urban Institute Ireland Working Paper Series, UCD UII 08/01, University College Dublin

Verburg PH, de Nijs TC, van Eck JR, Visser H, de Jong K (2004a) A method to analyse neighbourhood characteristics of land use patterns. Comput Environ Urban Syst 28:667-690

Verburg PH, de Nijs TCM, Ritsema Van J, Visser H, De Jong K (2004b) A method to analyse neighbourhood characteristics of land use patterns. Comput Environ Urban Syst 28:667-690 
Vezhnevets V, Konouchine V (2005) GrowCut: interactive multilabel ND image segmentation by cellular automata. In: Proceedings of graphicon, 2005. Citeseer, pp 150-156

Wagner DF (1997) Cellular automata and geographic information systems. Environ Plan 24:219-234

White R (1998) Cities and cellular automata. Discret Dyn Nat Soc 2:111-125

White R, Engelen G (1993) Cellular automata and fractal urban form: a cellular modelling approach to the evolution of urban land-use patterns. Environ Plan A 25:1175-1199

White R, Engelen G, Uljee I (1997) The use of constrained cellular automata for high-resolution modelling of urban land-use dynamics. Environ Plan 24:323-343
White R, Engelen G, Uljee I, Lavalle C, Enrlich D (1999) Developing an urban land use simulator for European cities. In: Proceedings of the 5th EC-GIS Workshop. Stresa, Italy

Wolfram S (1983) Statistical mechanics of cellular automata. Rev Mod Phys 55:601

Wolfram S (1984) Universality and complexity in cellular automata. Phys D 10:1-35

Wu F (1998) An experiment on the generic polycentricity of urban growth in a cellular automatic city. Environ Plan B Plan Des 25(5):731-752

Wu F, Webster CJ (1998) Simulation of land development through the integration of cellular automata and multicriteria evaluation. Environ Plan 25:103-126 